\title{
Translation and Political Struggle in Exile: The Chile Group
}

\author{
Montserrat Bacardí* (Facultat de Traducció i Interpretació, Universitat Autònoma de Barcelona) \\ Montserrat.Bacardi@uab.catｈttp://orcid.org/0000-0001-9593-7928
}

\begin{abstract}
One of the consequences of the 1939 exile was the widespread emergence, or re-emergence, of cultural community centres, periodicals and magazines, brief treatises and books that gave priority to local events over outside influences. Xavier Benguerel, Domènec Guansé, C. A. Jordana, Joan Oliver and Francesc Trabal, who formed the Chile group, held translation as their weapon of choice in the political and cultural struggle. Here, we look at the most remarkable achievements, collective strategies and ways of thinking about language and translation.
\end{abstract}

Keywords: exile, Catalan translation, Catalan literature, Xavier Benguerel, Domènec Guansé, C. A. Jordana, Joan Oliver, Francesc Trabal

\section{Background and prolegomena}

Towards the end of January 1939, with the "nationals" hot on their heels, the population committed to the government of the Republic sought to flee Catalonia however they could. The institutional initiative of the Council for Culture assembled a good number of writers who left in two turns on 23 and 24 January: some of them formed what was known as the Andean Group ${ }^{1}$, which included Xavier Benguerel, Domènec Guansé, Cèsar-August Jordana, Joan Oliver and Francesc Trabal. After spending some time in Toulouse and a further period in Roissy-en-Brie (on the outskirts of Paris), they arrived in Chile on 9 January 1940 aboard the Florida, with the help of Pablo Neruda, the Chilean consul in Paris who, on paper, made them industrial or agricultural "experts", which was an essential requirement for gaining entry.

Each one of them already had a considerable baggage from the past: Benguerel, the youngest, had published four novels, a series of short stories, a volume of poetry and a play; Guansé had worked prolifically in the press and had also written narrations, nouvelles and novels, as well as three pieces for the theatre; the eldest, Jordana, was head of the Office for the Correction of Style at the Generalitat and had already written six narrative works and a dozen or so more works of grammar, literary and cultural dissemination, as well as numerous articles; Oliver had also become known as a poet with three published books, narrator (with two), playwright (five works) and

\footnotetext{
*Montserrat Bacardí is Professor at the Universitat Autònoma de Barcelona. She has published articles on translation and literary history and the books Cent anys de traducció al català (1891-1990) (1998), Anna Murià. El vici d'escriure (2004), El Quixot en català (2006), Catalans a Buenos Aires (2009), La traducció catalana sota el franquisme (2012), Gràcia Bassa, poeta, periodista i traductora (2016) and, together with Pilar Godayol, Diccionari de la traducció catalana (2011) and Les traductores i la tradició (2013).

1 “As the dissidents or European enragés called us" (Benguerel 1971: 395).
} 
journalist; finally, Trabal, a cultural activities and organisational leader of the group, had published six novels and a book of jokes.

They also had experience as translators, with the exception of Benguerel and Trabal. Oliver had translated a story by Jules Superville, Guansé the French classics such as Balzac, Louÿs, Maupassant, Prévost and Voltaire. Jordana had become something of a reference in translation - especially from English - in classical plays, with two works by Shakespeare for an aborted project for the complete works, as well as modern and contemporary narrative: Dickens, Hardy, Walter Scott, Stevenson, Mark Twain, H. G. Wells and Virginia Woolf.

During their year in France, Benguerel, Guansé, Jordana, Oliver and Trabal tried to continue with their intellectual activities, as a result of the efforts of Trabal, who managed to organise stays at the Maison des Pompiers in Toulouse and the castle at Roissy-en-Brie. The shock produced by so much loss did not dilute their creative force, as can be seen in a number of articles that appeared in magazines dedicated to emigration and the first publications in exile, the works actually undertaken and the projects in the pipeline. Domènec Guansé, the reporter for the first intellectual exodus, testified to the events in a collection of articles printed in Catalunya (Guansé 1939a; 1939b). Xavier Benguerel described his personal experiences during that period of transit: when he was still in Barcelona, packing his bags, he managed to jam in "some papers I had in the drawer of my bedside table: translations of some poems" (Benguerel 1971: 280); in Toulouse, at the old fire station where they were received, he carried on working and, once in Paris, he received a sum of 3000 francs from the Fundació Ramon Llull for his literary work - money that would go towards reuniting his family. Francesc Trabal was also recompensed for some supposed translations, an "administrative" term that would have covered the collective compositions that he had organised (La cultura catalana 2000: 123).

The first publisher in exile was set up in Buenos Aires. Under the umbrella of Catalunya, the Help Group for Catalan Culture was set up with the aim of "bringing together the word inspired by our poets and our writers" (Benguerel 1939: 7). Did translation remain outside this and the other collections that appeared? De facto, it did, since there were only limited resources and it could not operate within the laws of a regular market: to put it bluntly, the potential public had become volatile. The first two volumes of the Group (of the six that would appear) corresponded to the Chilean nucleus: Sense retorn (1939), by Benguerel, and Tres a la reraguarda (1940), by Jordana. At the presentation, Benguerel celebrated the initiative due to the fact that, since the victory of Franco, "every written and spoken word has an air of struggle" (Benguerel 1939: 13). If political commitment had banished them from the country, it also had to make up for the suffering of being in exile. It had to give them a sense of being, a reason for staying strong and active in the (softness) of brand new countries that attracted adventurers and bounty hunters.

Again, Francesc Trabal stepped up as the main person responsible for establishing links with the country of adoption and drumming up support for patriotic activism. Appeals to the Catalans took place through the articles published in Germanor: "We have to do what is necessary and what we are capable of at every moment. We have to surpass ourselves" (Trabal 2011: 89-90). He was head of a radio programme on literature, of the Chilean-Catalan Institute ${ }^{2}$, the PEN Club of Chile (where he created the Catalan section) and the Rapa-Nui children's publisher. He also organised the Spanish translation of his own novels, Judita (1941), by Manuel L. Salvat, and Vals (1945) and Temperatura (1947), by his friend Joan Oliver. All in all, he can be considered "the Catalan writer with the greatest prominence as a writer, strictly speaking, within the country where he ended up" (Campillo 2006: 252). It should be mentioned that later on, he began to disappear from the scene, worn down by the "moral damage" of distance (Oliver 1968: 49).

\footnotetext{
2 "A cultural organisation at the service of Chile and Catalonia and for spiritual exchange between the two countries" ("Els catalans a Xile" 1942: 28).
} 


\section{Germanor and Catalunya}

Part of the cost of the journey to Chile had been met by the Catalan Centre of Santiago, which received the group and opened up to it the doors of Germanor, the magazine founded in 1912 by Francesc Camplà. The March-May 1939 issue contained an anonymous note announcing that it had "ceased to be a local magazine" and had become the "voice of the spirit of Catalonia" ("Noves col-laboracions" 1939: 1). In April 1940, it underwent a change of format and content and thereafter began to be published with Benguerel, Guansé, Jordana and Trabal as its "writing team". Camplà's death in the middle of 1941 meant that Oliver was able to take over as chief editor, a post he held until 1943, when he resigned over a political disagreement. In January 1945, Guansé took over as editor and remained until the final issue 608 in March 1963 shortly before returning to Catalonia. In fact, since March 1951, the magazine had again been seen as a journal for the Centre: "it continued to print an average of a thousand copies but the dwindling number of readers and collaborators along with the economic crisis meant that the issues got thinner" (Manent 1989: 67-68).

So, the 1940s was the golden age of Germanor. With different types of involvement, the newcomers played their part in it, and they did so as if they had never moved away from home, using the resources that they had available to make a "normal" magazine for a "normal" public - modern and cosmopolitan and, at the same time, sensitive to the historic defeat they had experienced while being firmly rooted in the new country. Language and literature had to occupy pride of place, without losing sight of the political opinion and news service offered by all the publications of the migrants.

Consequently, and in all naturalness, the group began to insert translations. The first was a "Chilean tale" by Luis Durand, translated by Francesc Trabal. He never again did any translating, and those who up until then had been the most prolific translators were also fairly noted for their absence. As Jordana explained to Agustí Bartra on 8 April 1941, for him, translation was an arduous experience: "I work the full eight hours at the Ercilla publishing house, and three or four more doing translations from English for the same company" (Correspondència: 2005: 10). Guansé sporadically translated journalistic texts from the Chilean, Spanish and French press. But most of the literary translations were identified to Xavier Benguerel and Joan Oliver, either by their name, sometimes with their initials and sometimes under the pseudonym of the poet Pere Quart.

They shared the same source languages: French and Spanish. Benguerel also translated from English, which he was studying at the time "as if my objective [...] was exclusively to read and to translate" (Benguerel 1974: 75): he gave us the first Catalan versions of "Annabel Lee" and "The Raven" by Edgar A. Poe. Oliver enjoyed rewriting compositions from German by Rainer Maria Rilke using intermediate translations, justifying the practice with examples of illustrious precedents:

I confess that I do not know the original language of the poet translated. It has been enough for me to use Spanish and French versions, and a dictionary. I have proceeded in much the same way as Josep Carner and Marià Manent in their versions of Chinese poetry. On some points I have taken certain liberties; I don't know if I have always interpreted Rilke's thinking correctly. But I like my translation and I would like the readers to like it; and for it to contribute to the knowledge, among Catalans, of one of the purest and richest poets of all time. (Rilke 1941: 17)

It was the first argument for indirect translation, and on his return to Barcelona, he used the same method for Pygmalion by George Bernard Shaw and several works by Chekhov, and obviously, he focussed on the benefits of translation for the target language and culture.

On arrival in Chile, as mentioned above, Benguerel had already received economic recompense for "my versions of Verlaine, Rimbaud, Baudelaire, Mallarmé i Valéry" (Benguerel 1971: 375). They were his leading poets and he took advantage of Germanor to offer a taste of them, such as "El cementiri marí", by Paul Valéry, later retranslated (Ripoll 2009). In a demonstration of the affinity between him and Benguerel, the "homeless poets" (Steiner 2002: 24), Oliver took up the challenge of making French symbolists such as Mallarmé and Valéry 
speak Catalan. ${ }^{3}$ Jointly, they signed the translation of "Booz adormi", by Victor Hugo ${ }^{4}$, with their combined initials "X.O.". Oliver also rewrote five poems and two new narratives by Jules Superville and, once back in Barcelona, a scene from Molière's Misantrope. ${ }^{5}$ Both Benguerel and Oliver translated other texts by Superville, but they have remained unpublished. In short, in Santiago, they tied strong knots of translational complicity, which they maintained for years afterwards, as reflected in the superb Epistolari (1999).

In the same way, they made a big effort to distribute Chilean literature among Catalan readers, with news, articles and translations. They imposed the will to strengthen the relationship between the two peoples and clearly show their gratitude for the welcome they had received. So, Benguerel - and Oliver even more translated stories by Ricardo A. Latchman and Mariano Latorre as well as poems by Vicente Huidobro, J. Lagos Lisboa, Gabriela Mistral and Pablo Neruda.

In 1945, Mistral was awarded the Nobel prize, a pretext used by Germanor to highlight her work. It particularly valued her poetic works and her human side (simplicity, kindness and generosity), as well as the links that she had established previously: talking of a period in Barcelona, "already in 1935 she had publicly made manifest her love for Catalan culture" ("Gabriela Mistral" 1945: 1). In an article in the celebrated section "The hour of the witch", Joan Oliver made an existentialist reading of her, in which he specifically underlined "a certain negligence in her art", "a radical originality, the definitive force of her message" (Oliver 1945: 9), universal and lasting.

The return of Pablo Neruda to Chile was the motive for a special section in recognition of him in the first issue of Senyera, a magazine edited by Oliver from 1943 to 1944, with a translation of the poem "General Franco in Hell", in recognition of his "active love towards us" (Neruda 1943: 5). Later, the Catalan community paid homage to him on 17 March 1945 (Campillo 2009b). The March issue of Germanor made a large impact with the publication of speeches by Xavier Benguerel and Pablo Neruda (translated by Guansé) and the version of Neruda's "Cant en la mort i resurrecció de Lluís Companys", signed by Pere Quart. Benguerel on the one hand praised his courage, which had enabled them to enter Chile, but also endowed him with a certain messianic reverence (very Neruda-like), vindicating the role of art in the political struggle: "we will reclaim our land if finally, from our hearts, we are able to turn it into poetry" ("Homenatge a Neruda" 1945: 15). ${ }^{6}$

In parallel, Benguerel and Oliver published translations of the same languages and the same, or related, authors in the five issues of Senyera that appeared, and, especially, in the Catalunya of Buenos Aires - one of the few publications in exile which paid for contributions (Bacardí 2009: 16-17). The first to be involved was Jordana, who published six Shakespearian sonnets in 1939. Benguerel produced versions of two poems by Alejandro Reyes, and others, from French, of poems by Pierre de Ronsard, Charles Baudelaire and Paul Valéry. The translations were often swathed with notes by Benguerel himself, giving him presence and "authority", explaining the motives for his choice and, more subtly, how he had gone about the work (Bacardí 1996). Oliver translated several poems by Gabriela Mistral from Spanish and also a first version of Cucurell o el cornut imaginari, (Molière's “The Imaginary Cuckold”), which he later reworked. The length of the work meant that a note of justification was necessary: "Our magazine does not customarily publish complete works for the theatre. We have made an exception in this case of the excellent French comic playwright in consideration of the prestige of the translator, the eminent Joan Oliver ("Pere Quart") and in recognition of his work of adaptation to our language and surroundings" (“Cucurell" 1941: 11). The article was headed with an introduction by Domènec Guansé, who placed it in the context of a tradition of translations of Molière, describing some of the distinctive traits and heralding the positive effect of the shock effect that Catalan literature was capable of:

\footnotetext{
${ }^{3}$ According to the account of C. A. Jordana, while on board the Florida on the voyage to Chile, the work of Valéry had already been the subject of debate: "Xavier, Domènec and Joan, the poet, are discussing Paul Valéry" (Jordana / Guansé / Oliver / Benguerel 1994: 54).

4 "The best poem by Victor Hugo translated for the first time into Catalan" (Hugo 1940: 31).

5 "He seems to have fatefully thrown himself into translating the complete works of Molière" ("El Misantrop" 1949: 11), a project that he was unable to carry forward.

Years later, now in Barcelona, Benguerel rekindled his personal and literary relationship with Neruda and translated a number of his poems (Benguerel 1974: 133-165; 1982: 77-85).
} 
"those of us who [...] had suggested that Catalan theatre should break out from its home-grown roots [...] can only feel joyful about this persistence in the cult of Molière" ("Cucurell" 1941: 3).

Finally, translation occupied a significant place in El Pi de les Tres Branques, an initiative led by Benguerel and Oliver, which published seven works between 1947 and 1952. In the initial phase, there were three collections: a "Catalan literary series", some "documents of our times" and "Catalan versions of foreign works" - for the last of these, some of the programmed books were announced:

The following translations have been commissioned: Fragments, by Novalis (a version from the German by J. Ferrater Mora); Viatge sentimental, by Sterne (version from the English by Xavier Benguerel); Isabel, by Gide (version from the French by, Joan Oliver); Antologia de contes xilens (version by Domènec Guansé); Caliban parla, by Guehènno (version from the French by Salvador Sarrà).

Outside that series a special Edition of the Catalan poem by Paul Valéry El cementiri marí, translated in verse by Xavier Benguerel will be published with illustrations by Carles Fontserè. ("El Pi de les Tres Branques" 1947: 54-55)

Only the shortest appeared in the end, in the form of an opuscule. Because of a lack of resources, once again priority was given to original works. However, some of the translations had already been started, as seen in a letter dated 1 October 1947 from Oliver to his wife, Conxita Riera: "I am translating the novel Isabel by Gide for El Pi de les Tres Branques" (Oliver 2000: 68). Gide was not Catalanised again, following the disaster of 1939, until the 1980s.

\section{Translation and language}

Behind this series of translations, a fairly defined concept of translation and language can be perceived, in keeping with the circumstances and as a way of understanding the cultural acts. Benguerel, Guansé and Oliver timidly approached questions of translation, while Jordana and Oliver tackled other questions of language.

In practice, for the Chile group, translation meant appropriation, domestication, in the sense of approaching a linguistic and conceptual subject and also in the sense of educating or teaching. If the interest in literature resided initially in the choice of authors and texts, in the final result, it was the supposed "pedagogical" interest for the potential readership that prevailed. The translation had to be read with the same "naturalness" as the original works and, at the same time, had to establish a model of language, or even forge one, as in the case of Josep Carner, whose translations were considered "a delightful search for relations between languages and a deep understanding of Catalan" (Jordana 1959: 195). Strict faithfulness was obviously resented. For that reason, for his version of Cucurell, Guansé maintained that "more than a translation it is a reworking or recreation" ("Cucurell" 1941: 3): In the same sense, Oliver expressed himself by Catalanising the words of Molière, recreating them and making them his own. Benguerel worked in a similar way and did not deny that the admiration he held for the French symbolists led him to "try to make their poetry my own" (Baudelaire 1943: 4); this was seen even more explicitly in Ronsard's versions of the sonnets: "a translator [...] not only takes what he loves but turns it into the essence of himself" (Ronsard 1942: 4). The line between original and appropriated work was blurred, the original and the foreign voice became mixed because, in the end, everything came from the same "love of poetry and my own language" (Ronsard 1942: 4). If an ambitious creative work constituted an act of rebellion and national affirmation, the translation of another Western literature did the same. Similarly, translating from abroad meant opening up and modernising the Catalan language and literature, which was threatened under the blows of the regime and in peril of becoming isolated and subject to a certain "folklorisation". From the provisional homeland of Chile, Molière and Baudelaire were the best antidote, meaning that exile was, in fact, "not an inappropriate means of access to the universal" (Guillén 1998: 63).

From their adopted country, they could reflect on the language. In the inaugural issue of the new period of Germanor in April 1940, there was already a new section called "Defence of the language" by Arnau Bellcaire, 
a pseudonym of Jordana. In the first article entitled "General considerations", aimed at the "Catalans of America", there was a call for vigilance in the face of the inevitable interference of the adopted tongue, most of all taking into account the fact that in the freedom of expatriation, there was a need to preserve "our language in its purest beauty" (Bellcaire 1940a: 20). Even so, the group shared the idea that "purity" should not mean stiffness or artificiality. So, some months later, on more practical grounds, Jordana declared: "I would advise Catalans in Chile that, by using our language in writing, they will never forget how to speak it" (Bellcaire 1940b: 10), so that they would not fall into the trap of vain pretension or cloaked audacity.

Indirectly, Oliver also fought against verbal excesses and linguistic distortion in different pieces of writing, for instance, in some of his essays, such as those on Marsias and L'arbre de foc, by Agustí Bartra. On the other hand, he used Germanor to criticise others in the country who had changed their language (in particular, in the articles "Catalan books" and "Catalan vengeance"). With regard to the appearance of the new features in the works of Ignasi Agustí and Josep Pla, he ironised about "the improper and tinny language in which they are written" (Oliver 1946a: 9), a Spanish filled with Catalan influences that detract from the language and leave it without its own simple and skinny genius. It goes without saying that, in some cases, there was an underlying form of protest - as subtle as it was powerful - by the collaborationist "Catalan botifler writers" (Oliver 1946b: 17). Meanwhile, faithfulness to the language continued year after year among a considerable-sized group living far from home.

\section{No return?}

Of the five authors who set sail for Chile in December 1939, two - Francesc Trabal and C. A. Jordana - died there in 1957 and 1958, respectively. Both had become removed from collective Catalan activity, although they continued to write: Trabal published Temperatura (1947) and Jordana, El Rusio i el Pelao (1950) and posthumously, El món de Joan Ferrer (1971). Trabal, "failed in all the businesses he touched" (Oliver/Calders 1984: 52), mainly because he didn't mould himself to "this America which is so big to us" (Correspondència 2005: 23). Jordana, as seen previously, became a slave to correction and translation - jobs which he did "with pleasure but without excitement" (Guansé 1971: 9), first in Santiago and then in Buenos Aires, where he moved in 1945 to work for the Editorial Sudamericana publishing house. To make up for his intellectual solitude, he carried on learning languages - "I almost have German by the throat" (Busquets \& Grabulosa 1993: 111), he wrote to Benguerel in September 1953 - and translating to Catalan: Els bandits, by Schiller, and Egmont, by Goethe (Franquesa 2015). It was of no importance to him whether these versions had been commissioned or whether there was a demand for them from the publishers; if only for himself, he had to return to his own target language after having written so many pages in his borrowed tongue (Campillo 2009a).

Domènec Guansé was the last to return to Catalonia, in 1963. For more than 20 years, he had devoted his life to the Catalan Centre and to Germanor. While in Santiago, he wrote the first version of the Retrats literaris (1947), as well as the diary Ruta d'Amèrica, a couple of published novels, La pluja d'or (1950) and Laberint (1952), and another couple that remain unpublished (Corretger 2011). He made his own overall evaluation of the situation: "if you asked me what my profession was during those years I would say - I was an exile", or, in other words, "my work in Chile, as a whole, did not aspire to be a work of literary creation, but principally one of service texts" (Riera Llorca 1971: 50 i 55).

In Chile, Xavier Benguerel set up a pharmaceutical laboratory, which prospered. His homecoming was gradual, with several return trips until 1954, when he settled in Barcelona. Sense retorn (1939), written during the war, was the first work he published in exile. Before taking up the fertile profession of narrator again, translation served him to express himself and to experience a comforting historical and existential re-bonding, driven, like most of the exiles, by an "imperious need to re-establish their broken lives" (Said 2005: 184). It had a cathartic effect and, in the words of Guansé, "the translations fired the furnace that had always been ready" in the novelist (Guansé 1955: 242). 
Joan Oliver returned as soon as he could because "in exile, the only thing I wanted to do was return!" (Oliver/Calders 1984: 56). He did so with both fear and apprehension. To his activities as a committed intellectual before the war, now he could add those he had undertaken in Chile. On 1 November 1947, he confessed in a letter to Conxita Riera: "I have thought that some malevolent person could compromise me because of the things I wrote in G. [Germanor]" (Oliver 2000: 81). He was not prepared to abandon his principles and ideas at any cost: "If coming here I have to take part in any undignified, embarrassing or humiliating activity then I will have no option but to refuse". Without being involved in direct political action, he saw hope on the horizon to be able to "be involved in clean and bare Catalanism" (Oliver 2000: 45), as he had always done everywhere. He left Chile with a book of poetry, Saló de tardor (1947), and a pile of articles and translations. Afterwards, he became a recognised poet, a short-lived playwright, a journalist and a translator, both professional and vocational.

The Chilean circle - "the most representative of continuity" (Castellanos 2000: 43) - managed to create "a kind of cultural islet which was splendidly fruitful during a long decade" (Manent 1993: 144). It did not neglect the battle of translation, the form of writing that most directly connects Catalan literature, the most contumaciously persecuted by the Franco regime - whether silenced or errant - with the universal arts.

The reflection of Carles Riba as expressed in a letter to Xavier Benguerel on 13 August 1950 offers a final conjecture: "Have no doubt that what you do, you and your group in Chile, is followed, appreciated and loved [...]; you stand out for the good patriotic sense of your attitude, for the positive fertility of your action" (Cartes 1991: 453).

Attitude and action: we are left, effectively, with the experience of the struggle and a handful of works.

\section{Acknowledgements}

This article is the result of work by the consolidated research group "Grup d'Estudi de la Traducció Catalana Contemporània" (GETCC) (2014 SGR 285), of the Universitat Autònoma de Barcelona, and the R\&D project "La traducción catalana contemporánea: censura y políticas editoriales, género e ideología (1939-2000)" (FFI2014-52989-C2-1-P), financed by the Ministerio de Economía y Competitividad. Translation of the article was done by Fiona Kelso.

\section{References}

Bacardí, M.: “Les “relacions” by Xavier Benguerel”, Serra d’Or 439-440 (1996): 56-57.

Bacardí, M.: "La traducció catalana a l'exili. Una primera aproximació", Quaderns. Revista de Traducció 16 (2009):. 9-21.

Baudelaire, Ch.: "El viatge”, translated by Xavier Benguerel, Catalunya 147 (1947): 4-7.

Bellcaire, A.: “Consideracions generals”, Germanor 447 (1947a): 20.

Bellcaire, A.: “El català que s’escriu”, Germanor 453 (1940b): 10.

Benguerel, X.: Sense retorn, Buenos Aires, Agrupació d’Ajut a la Cultura Catalana, 1939.

Benguerel, X.: Memòries 1905-1940, Barcelona: Alfaguara, 1971.

Xavier Benguerel es confessa de les seves relacions amb La Fontaine, Edgar Allan Poe, Paul Valéry, Pablo Neruda, Barcelona: Selecta, 1974.

Benguerel, X.: Memòria d'un exili: Xile 1940-1952, Barcelona, Edicions 62.

Benguerel, X./Oliver, J.: Epistolari, edited by Lluís Busquets i Grabulosa, Barcelona. Edicions 62, 1999. 
Busquets i Grabulosa, L1.: “C. A. Jordana. Un epistològraf a l’exili”, Revista de Catalunya 78 (1993): 103-112.

Campillo, M.: "La construcció cultural a l'exili segons Francesc Trabal i Armand Obiols". In: Panyella, R./Marrugat, J. (eds.), L'escriptor i la seva imatge, Barcelona, L'Avenç, 2006, pp. 246-270.

Campillo, M.: “Cèsar-August Jordana, El món de Joan Ferrer", Quaderns. Revista de Traducció 16 (2009a): 2942 .

Campillo, M.: "Chile en el corazón. Los escritores del Florida y Pablo Neruda", Cuadernos Hispanoamericanos 711 (2009b): 77-85.

Castellanos, J.: "L’exili literari català: continuïtat i ruptura". In: Aznar Soler, M. ed., Las literaturas del exilio republicano de 1939, Sant Cugat del Vallès, GEXEL, pp. 31-44.

Correspondència amb Agustí Bartra des de l'exili xilè. Cartes de C. A. Jordana, Domènec Guansé i Francesc Trabal, edited by Jaume Aulet, Terrassa, Ajuntament de Terrassa, 2005.

Corretger, M.: Domènec Guansé, crític i novel-lista: entre l'exili i el retorn, Barcelona: Publicacions de l'Abadia de Montserrat, 2011.

“Cucurell o el cornut imaginari. Comèdia de Molière. Traduïda al català per Pere Quart”, Catalunya 132 (1941). 3-11.

“El Misantrop de Molière en la versió de Pere Quart”, Germanor 543 (1949): 11-12.

“El Pi de les Tres Branques”, Germanor 520 (1947): 54-55.

“Els catalans a Xile. Constitució del 'Centro Chileno-Catalán de Cultura”, Germanor 471 (1942): 28-29.

F[ranquesa], L1.: “Gabriela Mistral”, Germanor 501 (1945): 5-6.

Franquesa, M.: "Dos traducciones inéditas de C. A. Jordana en el exilio: Die Räuber de Schiller y Egmont de Goethe”, in Interacciones. Reflexiones en torno a la Traducción e Interpretación del/al alemán. Studien zur romanischen Sprachwissenschaft und interkulturellen Kommunikation, Frankfurt, Peter Lang, 2015, pp. 369386.

Guansé, D: “Catalans a Tolosa”, Catalunya 101 (1939a): 6-7.

Guansé, D: “El grup de Roissy-en-Brie”, Catalunya 102 (1939b): 3 and 9.

Guansé, D: “Xavier Benguerel, novel·lista”, Pont Blau 33 (1955): 242-245.

Guansé, D: "Notícia sobre C. A. Jordana”. In: Jordana, C. A., El món de Joan Ferrer, Barcelona: Proa, 1971, pp. 5-9.

Guillén, C.: Múltiples moradas. Ensayos de literatura comparada, Barcelona: Tusquets, 1978.

"Homenatge a Neruda. Els catalans homenatjaren al poeta xilè, el dia 17 de març de 1945. Discurs de Xavier Benguerel”, Germanor 494 (1945): 15.

Hugo, Victor: "Booz adormit”, translated by X. O., Gernamor 451 (1940): 31.

Jordana, C. A. “Josep Carner, traductor”. In: L’obra de Josep Carner, Barcelona, Selecta, 1959, pp. 194-197.

Jordana, C. A./Guansé, D./Oliver, J./Benguerel, X. París - Santiago de Xile. Quatre visions d'un mateix viatge a l'exili, edited by Lluís Busquets i Grabulosa, Barcelona: La Magrana, 1994.

La cultura catalana en el primer exili (1939-1940). Cartes d'escriptors, d'intel-lectuals $i$ científics, edited by Maria Campillo and Francesc Vilanova, Barcelona, Fundació Carles Pi i Sunyer, 2000.

Manent, A.. La literatura catalana a l'exili, Barcelona: Curial, 1989. 
Manent, A.: Retorn a abans-d'ahir. Retrats d'escriptors $i$ de polítics, Barcelona: Destino, 1993.

Neruda, P.: “El general Franco a l'infern”, translated by Pere Quart, Senyera 1 (1943): 5.

Neruda, P.: “Noves col-laboracions”, Germanor 436-478 (1939): 1.

Oliver, J.: “Gabriela Mistral, poetessa de la vida”, Germanor 502 (1945): 9-10.

Oliver, J.: "Llibres catalans", Germanor 503 (1946): 8-9.

Oliver, J.: "Venjança catalana", Germanor 506 (1946): 17-18.

Oliver, J.: "Francesc Trabal, recordat", Serra d'Or 100 (1969): 45-49.

Oliver, J./Calders, P.: Diàlegs a Barcelona, edited by Xavier Febrés, Barcelona: Ajuntament de Barcelona/Laia; 1999.

Oliver, J.: Marines soledats. Cartes a Conxita Riera, edited by Miquel Bach, Sabadell: Fundació La Mirada, 2000 .

Riba, C.: Cartes de Carles Riba II: 1939-1952, edited by Carles-Jordi Guardiola, Barcelona: La Magrana, 1991.

Riera Llorca, V .: Nou obstinats, Barcelona: Selecta, 1971.

Rilke, Rainer Maria: “Primera elegia de Duino”, translated by Pere Quart, Germanor 461 (1941): 17-18.

Ripoll, J. M.: “El teixit contra la barbàrie: El corb i El cementiri marí per Xavier Benguerel”, Quaderns. Revista de Traducció 16 (2009): 55-65.

Ronsard, P.: "Sonets per a Hel·lena”, translated by Xavier Benguerel, Catalunya 144 (1943): 4-6.

Said, E. W.: Reflexiones sobre el exilio. Ensayos literarios y culturales, Barcelona: Debate, 2002.

Steiner, G.: Extraterritorial. Ensayos sobre literatura y revolución lingüística, Madrid: Siruela, 2002.

Trabal, F.: Els contracops de l'enyorança. Escrits d'exili, edited by Maria Campillo, Sabadell: Fundació La Mirada, 2011. 